\title{
Prevalence of dermatoses in patients referred for evaluation in an outpatient clinic of specialties*
}

\author{
João Avancini ${ }^{1,2}$, Paola Zucchi ${ }^{3}$
}

DOI: http:/ / dx.doi.org/10.1590/abd1806-4841.20186640

\begin{abstract}
Background: Brazilian Unified Health System presents a long waiting period for a dermatology appointment, varying from 34 to 239 days.

ОвлестіVEs: Analyze the prevalence of cutaneous diseases evaluated by dermatologists in a specialized center, in patients referred from the primary care, and to present possible interventions for the primary units.

METHODs: Retrospective analyses of the International Codes of Diseases (ICD-10) described in every dermatology appointment in a specialty center in Sao Paulo from January 2014 to August 2015.

RESULTS: A total of 7.350 consultations were included. Superficial mycosis corresponded to 1,058 (14.4\%) of the main complaints and dermatophytosis was the most frequently used ICD, corresponding to 481 individual consultations (6.5\%), followed by onychomycosis, responsible for 464 consultations (6.3\%), acne in 347 (4,7\%). and contact dermatitis in 311 consultations $(4,2 \%)$. STUDY LIMITATIONS: The study was based on retrospective analysis of ICD described and no previous orientation for a solid use of the codes was performed to the dermatology team; consultations in which the ICD was not informed or a non-especific ICD was used were excluded; different dermatologists were responsible for the consultations.

ConCLusion: Superficial mycosis corresponded to $14.4 \%$ of the chief complaints in the studied period and was the most frequent cause of reference from primary care doctors to dermatologists. Prevalence data obtained in the present study could assist the capacitation policies in the primary care system, focusing the dermatology teaching in the most prevalent dermatological disorders.
\end{abstract}

Keywords: Budgets; Dermatomycoses; Health economics; Health impact assessment; Mycoses; Onychomycosis

\section{INTRODUCTION}

There is a high demand for treatment by medical specialists in Brazil's public Unified Health System (SUS), leading to an imbalance in the supply and demand for care. Patient care in specialized outpatient clinics involves extremely long waiting time, from the request for the appointment until the patient is actually seen by the specialist. Waiting time in dermatology varies from 34 to 239 days according to the area in the city of São Paulo. ${ }^{1}$ The reasons for referral to dermatologists include skin diseases with widely varying degrees of complexity.

Various skin lesions call for specialized evaluation that requires specialized training in Dermatology in order to raise consistent diagnostic hypotheses, therapeutic proposals, and surgical approaches (whenever necessary). However, some highly prevalent skin diseases are easy for the general practitioners to diagnose and treat, including superficial mycoses, especially on the feet and inguinal region, besides nail mycosis (onychomycosis), with an estimated $2-9 \%$ prevalence in the general population. ${ }^{2,3}$

The aim of this study was to analyze the prevalence of skin diseases assessed by dermatologists in a specialized outpatient clinic in patients that had been referred from primary care. Such information is potentially useful for decision-making on policies for training primary care physicians. Interventions for training health teams based on prevalence studies can lead to budget optimization and reductions in waiting time.

Received 06 November 2016 .

Accepted 24 May 2017.

* Work conducted at Universidade Federal de São Paulo (Unifesp), São Paulo (SP), Brazil.

Financial Support: None.

Conflict of Interest: None.

Dermatology Division, Hospital das Clínicas, Faculdade de Medicina da Universidade de São Paulo, São Paulo (SP), Brazil.

Master's Student in Administration, Health Economics and Management. Universidade Federal de São Paulo, São Paulo (SP), Brazil.

Discipline of Health Economics and Management, Universidade Federal de São Paulo, São Paulo (SP), Brazil.

MAILING ADDRESS:

João Avancini

E-mail: joao.avancini@hc.fm.usp.br

(C)2018 by Anais Brasileiros de Dermatologia 


\section{METHODS}

We conducted a retrospective analysis of the codes from the International Classification of Diseases (ICD-10) recorded in patient files by dermatologists at the end of each consultation in a Municipal Specialized Outpatient Clinic called "Rede Hora Certa Lapa", located in the West Zone of the city of São Paulo. The clinic was previously known as "AMA E Sorocabana" and is managed by the nonprofit Social Organization called Associação Saúde da Família. The study covered a 20-month period, from January 1, 2014, to August 31, 2015. Data were made available by the Lapa-Pinheiros Regional Coordinating Division in November 2015, formatted on an Excel table $\left(\right.$ Microsoft $\left.{ }^{\circledR}\right)$, specifying each individually recorded ICD, the name of the attending dermatologist, date of the consultation, and patient's age and sex. The data were obtained with the BI-SIGA tool in the SIGA database (Sistema de Informação Integrado e Distribuído, focused on integrated management of the Unified Health System-SUS), under the Municipal Government of São Paulo. The research project was approved by the Institutional Review Board of the São Paulo Municipal Health Secretariat and the Research Ethics Committee of Universidade Federal de São Paulo (case review 1.135.288). All consultations performed during the study period had the ICD assessed, and those for which the ICDs had not been recorded were excluded. Figure 1 shows the flowchart with the study's inclusion and exclusion criteria.

\section{RESULTS}

We reviewed the ICDs recorded for 9,368 patient consultations performed from January 1, 2014, to August 31, 2015. Table 1 shows the ten ICDs that were reported most frequently by dermatologists during the study period. Of the 9,368 consultations, 2,018 $(22 \%)$ were excluded because the attending dermatologist had not recorded an ICD, leaving 7,350 consultations to be analyzed. Considering the 7,350 consultations included in the study, superficial mycoses accounted for 1,058 (14.4\%) of the chief complaints. Table 2 shows the codes recorded for the superficial mycoses and the breakdown by subtypes. Ringworm or dermatophytosis (unspeci- fied) was the most frequently recorded ICD, with 481 consultations $(6.5 \%)$, followed by tinea unguium (onychomycosis), the chief complaint in 464 consultations (6.3\%).

\section{DISCUSSION}

In the current study, superficial mycoses accounted for $14.4 \%$ of the chief complaints in dermatology consultations and were the leading cause of skin diseases assessed during the study period. Among the specified superficial mycoses, the most common was onychomycosis ( $43.8 \%$ of the superficial mycoses). These data agree with the literature, indicating that superficial mycoses are among the world's most frequent skin lesions. ${ }^{4}$ An estimated $20-25 \%$ of the general population has fungal skin infections, and

\begin{tabular}{|c|c|c|}
\hline $\begin{array}{l}\text { Disease correspon- } \\
\text { ding to recorded ICD }\end{array}$ & $\begin{array}{c}\text { Number of } \\
\text { patient } \\
\text { consultations }\end{array}$ & $\begin{array}{l}\text { Percentage of total } \\
\text { consultations in } \\
\text { the study }\end{array}$ \\
\hline Dermatophytosis & 481 & $6.5 \%$ \\
\hline Tinea unguium & 464 & $6.3 \%$ \\
\hline $\begin{array}{l}\text { Disorders of the skin } \\
\text { and subcutaneous tis- } \\
\text { sue, unspecified }\end{array}$ & 408 & $5.6 \%$ \\
\hline Acne & 347 & $4.7 \%$ \\
\hline Contact dermatitis & 311 & $4.2 \%$ \\
\hline Melasma & 273 & $3.7 \%$ \\
\hline Seborrheic keratosis & 245 & $3.3 \%$ \\
\hline $\begin{array}{l}\text { Melanocytic nevus, } \\
\text { unspecified }\end{array}$ & 205 & $2.8 \%$ \\
\hline Viral warts & 204 & $2.8 \%$ \\
\hline $\begin{array}{l}\text { Benign neoplasm of } \\
\text { the skin, unspecified }\end{array}$ & 163 & $2.2 \%$ \\
\hline
\end{tabular}

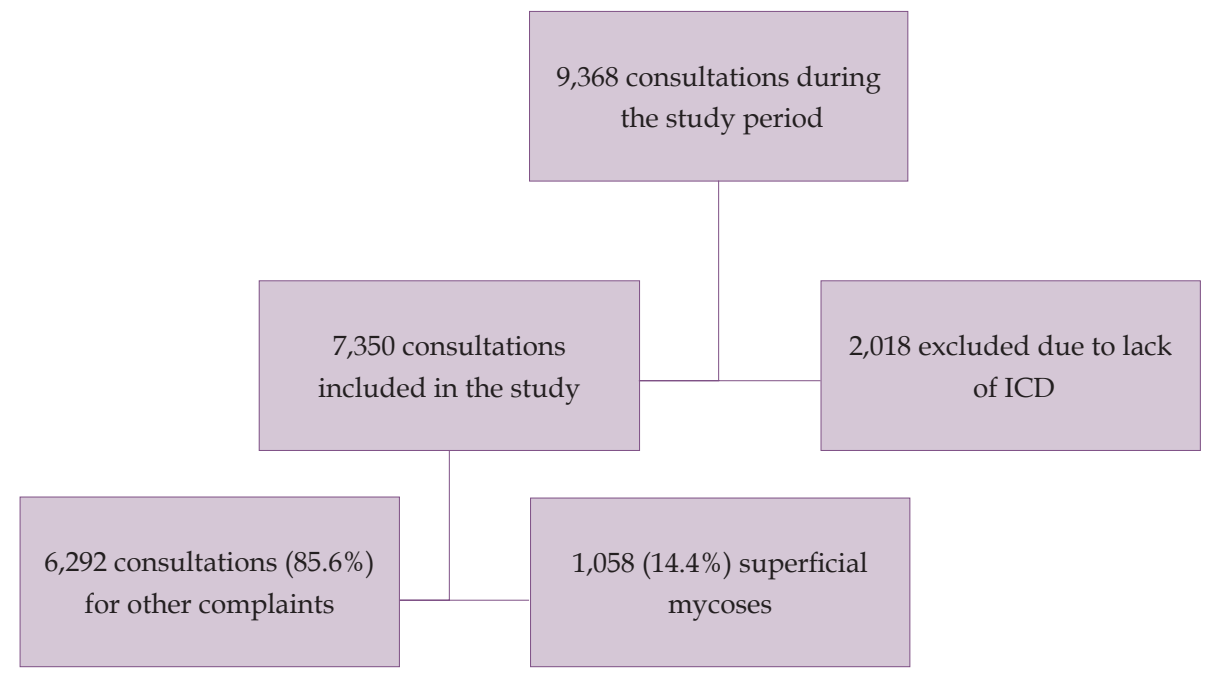

Figure 1: Algorithm for the study's inclusion and exclusion criteria: record of the number of cases of superficial mycoses in the sample 
TABLE 2: Breakdown of subtype of superficial mycoses assessed during the study period.

\begin{tabular}{|c|c|c|c|c|c|c|}
\hline Breakdown of superficial mycoses & 2014 & $\begin{array}{c}\text { Percentage of } \\
\text { consultations in } \\
2014\end{array}$ & $2015 *$ & $\begin{array}{c}\text { Percentage of } \\
\text { consultations in } 2015\end{array}$ & TOTAL & $\begin{array}{l}\text { Percentage of all } \\
\text { consultations } \\
\text { in the study period }\end{array}$ \\
\hline Dermatophytosis & 242 & $5.4 \%$ & 239 & $8.2 \%$ & 481 & $6.5 \%$ \\
\hline Tinea unguium & 314 & $7.1 \%$ & 150 & $5.2 \%$ & 464 & $6.3 \%$ \\
\hline Dermatophytosis, unspecified & 34 & $0.8 \%$ & 12 & $0.4 \%$ & 46 & $0.6 \%$ \\
\hline Other superficial mycoses & 11 & $0.2 \%$ & 22 & $0.8 \%$ & 33 & $0.4 \%$ \\
\hline Tinea pedis & 12 & $0.3 \%$ & 2 & $0.1 \%$ & 14 & $0.2 \%$ \\
\hline Superficial mycosis, unspecified & 7 & $0.2 \%$ & 1 & $0.0 \%$ & 8 & $0.1 \%$ \\
\hline Tinea corporis & 4 & $0.1 \%$ & 2 & $0.1 \%$ & 6 & $0.1 \%$ \\
\hline Tinea manus & 1 & $0.0 \%$ & 2 & $0.1 \%$ & 3 & $0.0 \%$ \\
\hline Tinea cruris & 1 & $0.0 \%$ & 0 & $0.0 \%$ & 1 & $0.0 \%$ \\
\hline Other specified mycoses & 1 & $0.0 \%$ & 0 & $0.0 \%$ & 1 & $0.0 \%$ \\
\hline Other dermatophytoses & 0 & $0.0 \%$ & 1 & $0.0 \%$ & 1 & $0.0 \%$ \\
\hline Total no. patients included & 4,446 & & 2,904 & & 7,350 & \\
\hline Total no. superficial mycoses & 627 & $5.6 \%$ & 431 & $14.8 \%$ & 1.058 & $14.4 \%$ \\
\hline
\end{tabular}

onychomycosis can be identified in $2-9 \%$ of the population. ${ }^{2,3,5,6} \mathrm{Di}$ Chiacchio observed the prevalence of onychomycosis in patients seeking dermatologic treatment for various complaints, among a sample of 7,852 patients from various regions of Brazil, and concluded that $28.3 \%$ presented the infection. ${ }^{6}$

Diagnostic confirmation in suspected cases of onychomycosis or other superficial mycoses can be performed by direct mycological examination and culture of the collected material, available in the primary care laboratories of the SUS. The appropriate medications are also provided free of cost by the SUS; ketoconazole cream is recommended for mild superficial mycoses, and oral fluconazole is used in onychomycoses and more extensive superficial mycoses.-9 In the authors' opinion, only cases involving diagnostic doubt or therapeutic failure would justify referral to the specialist.

Primary services encourage training their professionals in order to increase the case-resolution capacity for the patients seen there. The definition of priority themes requires knowledge on prevalence of the diseases. Little is known about the prevalence of skin diseases seen in secondary services in Brazil, which limits proposals for interventions to optimize health services. In 2007, Santos Junior et al. studied the prevalence of skin diseases in primary care in the city of Campinas, São Paulo State, and concluded that $18.59 \%$ of the users of primary healthcare services had some complaint related to a skin condition (primary complaint or identified in the complementary workup). ${ }^{10}$ Macaya-Pascual et al. analyzed the reasons for consultations and the associated costs in a primary care center in Spain, and found a high number of aesthetic consultations, accounting for $25 \%$ of the complaints. ${ }^{11}$ Martínez-Martínez et al., in another study in Spain, analyzed the proportion of what were considered ordinary diseases in referrals from primary care to dermatologists, divided into a group of benign degenerative diseases and trivial lesions that mainly included acrochordons, seborrheic keratoses, and intradermal nevi, concluding that $19.1 \%$ of the referrals did not justify specialized care ${ }^{12}$ However, although all of the above are benign lesions, we feel that the precise diagnosis should be made by a der- matologist, since such lesions can represent differential diagnoses with malignant skin cancers and thus require detailed evaluation. In the current study, as shown in the data in table 1, except for the simple forms of superficial mycoses, the authors believe that the other skin diseases that were prevalent during the study period actually require evaluation by a specialist.

The study has the following limitations: this was a retrospective study of the recorded ICD codes, without prior instructions or training for the dermatology staff in relation to the need for detailed completion of the codes, for use in subsequent research; in a large share of the patient consultations (22\%), no ICD code had been recorded; among the recorded ICDs, 408 (5.6\%) were not specified (unspecified disorders of the skin and subcutaneous tissue); different dermatologists were in charge of the care, and a total of 8 provided data on care during the study period; there were restrictions in the specification of the subtype of superficial mycosis, and ringworm or dermatophytosis (dermatophyte infection, unspecified), the most frequent, could represent mycoses of the skin and/or nails; and only one ICD could be recorded per consultation, thus limiting the evaluation of secondary complaints.

\section{CONCLUSION}

Superficial mycoses accounted for $14.4 \%$ of the main causes of care during the study period and were the most frequent causes of referral to dermatologists. Since these are common diseases and the diagnostic methods and usual medications are available in the primary care network, their diagnosis and treatment can be performed directly by the general practitioner, with no need for evaluation by a specialist. Data on prevalence from the study can assist training policies in primary care services, focusing on the fundamentals of dermatology in the most prevalent skin diseases. $\square$

\section{ACKNOWLEDGMENTS:}

The authors wish to thank Dr. Marlos Pontes and Marcello de Paschoal for their kind assistance in obtaining the data. 


\section{REFERENCES}

1. Capital.sp.gov.br [Internet]. Fila de exames cai mais de $50 \%$ em dois anos na rede pública de São Paulo [accessed 22 May 2017]. Available at: http://www.capital. sp.gov.br/noticia/fila-de-exames-cai-mais-de-50-em-dois-anos-na-rede.

2. Gill D, Marks R. A review of the epidemiology of tinea unguium in the community. Australas J Dermatol. 1999;40:6-13.

3. Roberts DT. Prevalence of dermatophyte onychomycosis in the United Kingdom: results of an omnibus survey. Br J Dermatol. 1992;126:23-7.

4. El-Gohary M, van Zuuren EJ, Fedorowicz Z, Burgess H, Doney L, Stuart B, et al. Topical antifungal treatments for tinea cruris and tinea corporis. Cochrane Database Syst Rev. 2014; CD009992.

5. Havlickova B, Czaika VA, Friedrich M. Epidemiological trends in skin mycoses worldwide. Mycoses. 2008;51:2-15.

6. Di Chiacchio N, Suarez MV, Madeira CL, Loureiro WR. An observational and descriptive study of the epidemiology of and therapeutic approach to onychomycosis in dermatology offices in Brazil. An Bras Dermatol. 2013;88:3-11.

7. Welsh 0, Vera-Cabrera L, Welsh E. Onychomycosis. Clin Dermatol. 2010;28:151-9.
8. Dias MF, Quaresma-Santos MV, Bernardes-Filho F, Amorim AG, Schechtman RC, Azulay DR. Update on therapy for superficial mycoses: review article part I. An Bras Dermatol. 2013;88:764-74.

9. Prefeitura.sp.gov.br [Internet]. Relação de Medicamentos Essenciais para a Rede Básica e Especialidades. Lista A, Lista B, Lista C February/2015 [accessed 22 May 2017] Available at: http://www.prefeitura.sp.gov.br/cidade/ secretarias/upload/saude/RelacaodeMedicamentos EssenciaisparaaRedeBasicae Especialidadesfevereiro2015(2).pdf.

10. Santos Júnior A, Andrade MGG, Zeferino AB, Monte Alegre S, Moraes AM, Velho PENF. Prevalence of dermatoses in the primary health care system of Campinas, São Paulo - Brazil. An Bras Dermatol. 2007;82:419-24.

11. Macaya-Pascual A, Lopez-Canos R, Lopez-Piqueras S, Gomez S. Análisis de los motivos de consulta y de su coste en la asistencia dermatológica en un centro de Atención Primaria. Actas Dermosifiliogr. 2006;97:569-72.

12. Martinez-Martinez ML, Perez-Garcia LJ, Escario-Travesedo E, RodriguezVazquez M, Azana-Defez JM, Martin de Hijas Santos MC. Demanda derivada a Dermatología: peso de la patología banal. Actas Dermosifiliogr. 2011;102:193-8.

\section{AUTHORS CONTRIBUTION}

João Avancini

(D) ORCID 0000-0003-3038-6373

Statistical analysis; Approval of the final version of the manuscript; Conception and planning if the study; Elaboration and writing of the manuscript; Obtaining, analyzing and interpreting the data; Critical review of the literature
Paola Zucchi
(iD) ORCID 0000-0002-0672-1584

Effective participation in research orientation

How to cite this article: Avancini J, Zucchi P. Prevalence of dermatoses in patients referred for evaluation in an outpatient clinic of specialties. An Bras Dermatol. 2018;93(4):513-6 